to a lag in the rearrangement of its molecules, as the external form of the contractile elements changes. This viscosity hypothesis is, however, altogether unnecessary; for the decrease of force and work with increased speed can be deduced from the manner in which the energy liberation is regulated. Some applications were also described. The maximum power developed by a muscle is with a load about three tenths of the maximum load it can bear. The highest efficiency (work/total energy) is with a load of about 0.45 of the maximum. These are near enough for maximum power and maximum efficiency to oceur very nearly at about 37 per cent of the maximum load. These results obtained with frog's muscle almost certainly apply, though possibly with different constants, to man, and it would be very important to find out and to determine the constants of human muscle. The technique required would be a very different one.

\section{Anthropoid Evolution in South Africa}

Dr. Robert Broom continues to provide sensational news from South Africa for anthropologist and palæontologist. In another column of this issue (see p. 897) he reports further finds of relics of South African fossil anthropoids, which, if anything, surpass in interest the remarkable discoveries he has already recorded recently in these columns. From the site on which was found the Kromdraai skull, he has now recovered three bones, or parts of bones, the right humerus, the ulna and one of the toe-phalanges of Paranthropus, which, as his nomenclature indicates, he places, on the evidence of the skull, very near the line of man. The new evidence fully bears out his conclusion, for as he states, these bones, which on the balance of probabilities must be associated with the skull, are "nearly human". Further, and this is the most interesting feature of the discovery, they, and more especially the toe bone, must be interpreted as pointing to Paranthropus having walked erect. In other words, the upper limbs of this type were already freed from the duties of locomotion to under. take those functions which were to play a predominant part in forwarding the development of the specific characters of the brain of Homo sapiens.

THIs eminently reasonable interpretation of the Kromdraai finds removes the element of surprise from the further discoveries from Sterkfontein, which Dr. Broom records; but it adds to their significance in mutual corroboration as between the two series of discoveries. At Sterkfontein, on the site on which he had previously discovered Plesianthropus trans. vaalensis, an advance towards the human on Prof. Raymond Dart's Australopithecus, or ape-man from Taungs, Dr. Broom has also found the distal end of a femur and part of the brain cast of, it is argued, a mature male. Not only would the fragment of femur suggest that this type of fossil anthropoid also had attained bipedal status, but in addition the brain cast, when reconstructed, would place the capacity of the brain of Plesianthropus next in the scale of measurement, so far as at present known, to the recently discovered specimen of Pithecanthropus from Java. Pithecanthropus, no longer in danger of being classed as a gibbon, is definitely above the human border-line. The new evidence from Kromdraai and Sterkfontein, taken in conjunction with the evidence of the symphyses, which Dr. Broom further records, would indeed seem to afford warrant for the view that we have been given a glimpse of the evolutionary process at a moment when what has been regarded hitherto as man's prerogative, the permanent assumption of the erect posture, had not long taken place. The difficulty in the way of regarding the South African fossil series as forming part of the human evolutionary process, though of course significant by analogy, on the ground of its relatively late date, to which Sir Arthur Keith has directed attention, is reduced, though not eliminated, by Dr. Broom's evidence for a revised dating.

\section{Scientific Associations of the Lubbock Estate}

THE public acquisition of the High Elms estate in Kent, as part of London's 'green belt', is an event of note in the history of science; for this was the home of the Lubbock family from 1808. In that year, Sir John William Lubbock acquired the nucleus of the property, some 270 acres; by later accretions the estate reached its present extent of nearly a thousand acres. A second Sir John William Lubbock was the first to bring scientific fame into the annals of the family : his observations of tidal and lunar phenomena and in physical astronomy ranked him high, and he was elected fellow of the Royal Society when barely twenty-seven years old. $\mathrm{He}$ worked also on the mathematical doctrine of probability and applied it practically to the subject of life assurance. $\mathrm{He}_{\mathrm{e}}$ became the first vice-chancellor of the University of London. He built the present mansion of High Elms, extended the property, and greatly beautified it by planting many of the splendid trees which grace it now. He was followed by a still more famous son, Sir John Lubbock, afterwards Lord Avebury, who, born in 1834, spent nearly all his life there, and succeeded to the property in 1865 . It is well known that on the scientific side his extraordinary career was influenced, not only by his father, but also, profoundly, by Charles Darwin.

IN fact, the assurance of the preservation of High Elms rounds off, as it were, a unique scientific memorial. For Down House is less than two miles from High Elrns, and Down House, as is well known, is preserved as a memorial to Darwin by the gift of Sir Buckston Browne to the British Association. It is on record that Sir John William Lubbock hailed as a great event the news that Charles Darwin was coming to live at Down House in 1842, and it was not long before intimacy was established between the two houses. Between Darwin, in his thirties, and John Lubbock, not yet in his teens, a close friendship grew and endured until Darwin's death in 1882, when Lubbock paid final tribute to his scientific master by drawing up the memorial which petitioned the Dean of Westminster that Darwin should be buried in the Abbey. It is good to know that not 
only the homes of these two renowned men, but also some at least of the countryside which they knew and loved, are safe from future change though suburban London lies so near.

\section{Jubilee of the Pasteur Institute, Paris}

November 14, 1938, marked the fiftieth anniversary of the inauguration of the Pasteur Institute of Paris as the result of international subseription, but the actual celebrations have, owing to the recent crisis, been postponed until December 27, the anniversary of the birth of Pasteur. The spacious building in the Rue Dutot, recently re-named Rue du Dr. Roux, took the place of the small laboratory in the Rue d'Ulm where so much of Pasteur's valuable work had been carried out. Although his labours were interrupted by ill-health during the rest of his life, he received the assistance of a number of collaborators and pupils, notably Roux, Yersin, Metchnikoff, Chamberland and Calmette. The institute at once became an important centre for bacteriological research, the results of which were published in the Annales de l'Institut Pasteur, founded in 1887, in which epoch-making papers appeared on rabies, anthrax, diphtheria toxin and antitoxin, and experimental syphilis, among many other important subjects.

IN 1903 the Annales were supplemented by the Bulletin de l'Institut Pasteur, which contained, as the title indicated, reviews and summaries of work on bacteriology, medicine, general biology, physiology and biological chemistry in relation to microbiology. The close association of the Institute with clinical medicine was shown by the subsequent establishment of the Pasteur hospital for infectious diseases on the opposite side of the street. Pasteur died on September 28,1895 , and after a public funeral was laid to rest in a magnificent tomb in a crypt of the Institute. Since his death, three eminent men have been in charge of the Institute, namely, Emile Duclaux (1895-1904), Emile Roux (1904-1933) and Louis Martin, the present director. Metchnikoff, Chamberland and Calmette were for some time sub-directors. Numerous Pasteur institutes modelled on that of Paris have been built in different parts of the world, such as those at Saigon (1889), Tunis (1893), Lille (1895), Algiers (1910) and Athens (1920).

\section{Violent Earthquake of November Io}

IT is reported from the Air Ministry that an earthquake of great violence was recorded on November 10 at Kew Observatory at 20 h. 30 m. 7 s. G.M.T., a second movement following about half an hour later. The displacements of the ground at Kew were about one tenth of an inch, and the epicentre of the shock was 5,100 miles away. This earthquake has been reported from observatories throughout the world. From New York it appeared to be at a distance of 3,400 miles and from Pasadena where the needles nearly went off the paper of the recording seismographs it appeared to be 2,550 miles. From the Dominion Observatory, Wellington, New Zealand, the epicentre appeared to be distant 6,000 miles, and from the Villa Ortoza Observatory in the Argentine more than 6,000 miles. At Mr. J. J. Shaw's Observatory at West Bromwich, it was reported to have had the largest amplitudes recorded in thirty years and to have been of greater violence than the Quetta earthquake of 1935 or the Tokyo earthquake of 1923. The shock was felt by people in Alaska though no damage was done, and it is reported in the Yorkshire Post to have been felt in Leeds. A small seismic sea wave was apparent on some of the Hawaiian Islands. All this evidence seems to point to a submarine epicentre in the North Pacific Ocean near the Aleutian Islands and to the south-west of Alaska. This area is known to be one of the unstable regions of the earth, about fifty large and many more small earthquakes being recorded from the vicinity between 1913 and 1930 .

\section{Earthquake near Vienna}

AN earthquake, with an epicentre near Vienna, occurred about 4h. G.C.T. on November 8, doing some damage to property, but causing no casualties. An earthquake in this region is most unusual, and the last one of any importance was in 1927 on October 8 at 19h. $48 \mathrm{~m}$. 55s. G.C.T. with epicentre lat. $48^{\circ} 04^{\prime}$ N., long. $16^{\circ} 35^{\prime} \mathrm{E}$. It was discussed very thoroughly by Dr. V. Conrad, of Vienna, who confirmed from the records the existence of the $P^{*}$ and $S^{*}$ waves. $\mathrm{He}$ considered that the depth of focus was near $30 \mathrm{~km}$., and that the thickness of the Granitic layer in this region was of the order of $40 \mathrm{~km}$. Further, Conrad found a pulse which he thought was caused at the A. Mohorovičić discontinuity $60 \mathrm{~km}$. deep under the earth's surface. It will be interesting to see whether or not these findings are confirmed by the present shock.

\section{Inventors and Inventions}

Sor JAmes Swinburne, in his presidential address delivered on October 25 to the Institute of Plastics, discussed the subject of invention. In his opinion, inventions are usually the work of men less than forty years of age and often are discovered by those without scientific training. $\mathrm{He}$ attributed this apparent anomaly to the likelihood of the technical man allowing his thought to be constrained in narrow grooves. The specialization of the modern world works against the interests of the home inventor. The day of the lone inventor has passed and progress is now usually the result of co-ordinated efforts of large research departments. Some of the greatest inventions have been, as a far-seeing judge once put it, what any fool might have done, but had not. Differentiating between the independent or outside inventor and the inside or technical man, Sir James believes that the latter is the former's chief enemy. When the independent worker approaches a commercial concern with an invention, he meets with opposition from the technical representative of the company, who is inspired by the human instinct of self-preservation, for the device submitted is something which the staff man feels that he himself ought to have thought of. A further distinction was drawn between the qualities necessary for an executive and 